\title{
Deneysel hayvan çalışmalarında montelukast
}

Prof. Dr. Berkant Özpolat

Kırıkkale Üniversitesi Tıp Fakültesi Göğüs Cerrahisi AD, Kırıkkale TÜRKiYE

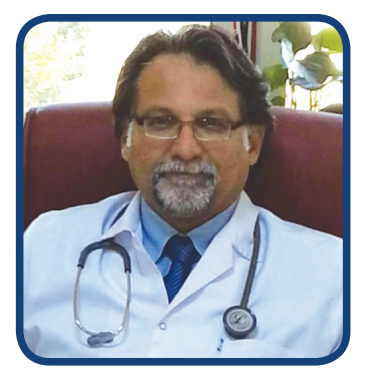

Son yıllarda sisteinil lökotrien (CysLT1) reseptör antagonisti, allerji ve astım tedavisinde kullanılan bir ilaç olan montelukastın deneysel çalışmalarda sıkıkla kullanıldığını görmekteyiz. TJCL'nin bu sayısında Budak ve ark. hepatik ve renal iskemi reperfüzyon modelinde yaptıkları çalışmada histopatolojik ve immünohistokimyasal olarak kanıtlanan olumlu etkinin, ilacın antioksidan ve antiinflamatuar etkilerine bağıı olduğu sonucuna varılmıştır [1].

Bilindiği üzere lökotrienler araşidonik asitten sentezlenen bir mediatördür ve eozinofil, bazofil ve mast hücreleri önemli lökotrien kaynaklarıdır. Lökotrienler damar geçirgenliğinde değişiklik, inflamatuar hücre birikimi, düz kas kasılması, mukus salgısında artma benzeri etkiler sebep olmaktadır.

Literatürde bu konuda yapılan deneysel hayvan çalısmalarında montelukastın solunum sistemini ilgilendiren çalışmalarda öncelikle astım ve alerjik rinit tedavisinde kullanıldığını görmekteyiz [2-4]. Tu ve ark. yaptığı çalışma transplantasyon sonrasında gelişen bronşiolitis obliteransın önlenmesi açısından umut verici görünmektedir [5]. Yumuşak doku çalışmalarında slikon implant yerleştirilmesi sonrası kapsül kontraksiyonu önlemede etkili olduğu belirtilmiştir [6,7]. Polat ve ark. tendon iyileşmesi üzerinde etkili olduğunu gösteren çalışmaları da dikkate değerdir [8]. Kognitif fonksiyonların restorasyonu ve demans tedavisi çalışmalarında kullanımı ve hafıza fonksiyonu üzerinde olumlu etkisi yapılan çalışmalarda ortaya konulmuştur $[9,10]$. Deneysel bir tıkayıcı sarılık modelinde karaciğer hasarı üzerine etkisi ve akut pankreatitin özellikle erken dönemlerinde faydalı olduğu gösterilmiştir [11,12]. Eskicioğlu ve ark. çalışmasında Overiyan Hipersitimülasyon Sedromunda kullanılabiieceği önerilmektedir [13]. Montelukastın kullanıldığı bir diğer çalışma periferik sinir sistemi hasarları üzerine yapılanlardır. Spinal kord hasarında iyileşmede olumlu etkisi bildirilmiştir [14,15]. Uçar ve ark. nın akut otitis tedavisinde en az penisilin kadar etkili olduğu gösterilmiştir [16]. Deneysel kanser çaıışmalarında Savari ve ark. nın kolon kanserinde tümör gelişimini durdurduğunu gösteren çalışması da oldukça ilgi çekicidir \{17].

Bu ve benzeri birçok çalışma ışığında, ileride montelukastın farklı alanlarda kullanılacağını öngörmek zor değil. Bunların başında inflamatuar hastalıklarda kullanımı, graft versus host reaksiyonlarının tedavisi ve özellikle kanser tedavisi konusunda yapılacak çalışmalar başı çekecektir.

Doi: $10.18663 / \mathrm{tjcl} .320026$

\section{Kaynaklar}

1. Budak AB, Korkmaz K, Gedik HS, et al. Effect of montelucast on hepatic and renal ischemia/reperfusion injury. Turk Clin Lab 2017; 8: 43-51.

2. Jung HW, Jung JK, Park YK. Comparison of the efficacy of KOB03, ketotifen, and montelukast in an experimental mouse model of allergic rhinitis. Int Immunopharmacol 2013; 16: 254-60.

3. Ikeda G, Miyahara N, Koga H, et al. Effect of a cysteinyl leukotriene receptor antagonist on experimental emphysema and asthma combined with emphysema. Am J Respir Cell Mol Biol 2014; 50: 18-29.

4. Sekioka T, Kadode M, Yonetomi Y, et al. CysLT2 receptor activation is involved in LTC4-induced lung air-trapping in guinea pigs. Eur J Pharmacol 2017; 794: 147-153. 
5. Tu ZL, Zhou ZY, Xu HC,et al. LTB4 and montelukast in transplantation-related bronchiolitis obliterans in rats. J Cardiothorac Surg 2017; $12: 43$.

6. Kim BH, Park M, Park HJ, et al. Prolonged, acute suppression of cysteinyl leukotriene to reduce capsular contracture around silicone implants. Acta Biomater 2017; 51: 209-219.

7. Yang JD, Kwon OH, Lee JW, et al. The effect of montelukast and antiadhesion barrier solution on the capsule formation after insertion of silicone implants in a white rat model. Eur Surg Res 2013; 51: 146-55.

8. Polat A, Canbora MK, Akakin D, Aykanat F. Effects of montelukast sodium on tendon healing: An experimental study. Indian J Orthop 2013; 47: 500-4.

9. Marschallinger J, Schäffner I, Klein B, et al. Structural and functional rejuvenation of the aged brain by an approved anti-asthmatic drug. Nat Commun 2015; 6: 8466 .

10. Kumar A, Prakash A, Pahwa D, Mishra J. Montelukast potentiates the protective effect of rofecoxib against kainic acid-induced cognitive dysfunction in rats. Pharmacol Biochem Behav 2012; 103: 43-52.

11. Kuru S, Kismet K, Barlas AM, et al. The Effect of Montelukast on Liver Damage in an Experimental Obstructive Jaundice Model. Viszeralmedizin 2015; 31: 131-8.

12. Angı S, Eken H, Kılıc E, Karaköse O, Balci G, Somuncu E. Effects of Montelukast in an Experimental Model of Acute Pancreatitis. Med Sci Monit 2016; 22: 2714-9.

13. Eskicioğlu F, Turan GA, Sivrikoz ON, et al. Montelukast is effective in preventing of ovarian hyperstimulation syndrome; an experimental study. Ginekol Pol 2015; 86: 566-73.

14. Cavus G, Altas M, Aras M, et al. Effects of montelukast and methylprednisolone on experimental spinal cord injury in rats. Eur Rev Med Pharmacol Sci 2014; 18: 1770-7.

15. Genovese T, Rossi A, Mazzon E, et al. Effects of zileuton and montelukast in mouse experimental spinal cord injury. Br J Pharmacol 2008; 153: 568-82.

16. Uçar S, Huseynov T, Çoban M, Sarıoğlu S, Serbetçioğlu B, Yalcin AD. Montelukast is as effective as penicillin in treatment of acute otitis media: an experimental rat study. Med Sci Monit Basic Res 2013; 19: 246-52.

17. Savari S, Liu M, Zhang Y, Sime W, Sjölander A. CysLT(1) R antagonists inhibit tumor growth in a xenograft model of colon cancer. PLoS One 2013; 8: e73466. 